\title{
EXAMINING THE PROPERTIES OF SINGLE- -ACTING HYDRAULIC DRIVE FOR VALVES OF INTERNAL COMBUSTION ENGINES
}

\author{
MARIUSZ SMOCZYŃSKI', TOMASZ SZYDŁOWSKI ${ }^{2}$ \\ Technical University of Lodz
}

\section{Summary}

The paper presents examination of the properties of single-acting hydraulic drive for valves of internal combustion (IC) piston engines. In the valve actuation system proposed, a Caterpillar solenoid valve of the HEUI fuel system and a commercial hydraulic actuator were used as the distributor and final control element, respectively. The examination was carried out on a specially prepared model of the valve actuation system under consideration. The influence of various construction parameters of the system on the course of the valve displacement process was examined, with analysing such characteristic parameters of the process as delay in the start of the valve motion measured from the beginning of the current control signal, valve opening and closing times, time of the valve kept open, valve displacement vs. time curve, filling ratio of the area under the valve lift curve, and velocity of the valve hitting its seat. The construction parameters whose impacts were analysed included oil supply pressure, total working space volume, power supply voltage, distributor solenoid force, cross-sections of the distributor supply and overflow gaps, total mass of moving distributor parts, engine valve mass, actuator piston diameter, and valve spring characteristic curve. The necessity of using high supply pressures and high control voltages has been proven. Guidelines for designing engine valve actuation systems of this type have been given. It has been shown that due to low flow capacity, the distributors of the type used are only suitable for the hydraulic actuation of small valves of high-speed IC engines. Evidence has been produced that systems to advance the control signal in relation to the required valve opening instant must be applied to compensate for the valve actuation delay and the limited valve opening velocity. The fact that the valve displacement vs. time curve may be shaped within a relatively wide range has also been pointed out.

Keywords: internal combustion engine, camless valve drive, hydraulic drive

\section{Introduction}

During the work carried out on the hydraulic actuation and timing of IC piston engine valves, a single-acting hydraulic drive system was tested as one of the possible options [1, 4]. In

\footnotetext{
${ }^{1}$ Technical University of Lodz, Department of Vehicles and Fundamentals of Machine Design, 116 Żeromskiego Street, 90-924 Łódź, Poland, e-mail: mariusz.smoczynski@p.lodz.pl, ph. +48 426312390

${ }^{2}$ Technical University of Lodz, Department of Vehicles and Fundamentals of Machine Design 116 Żeromskiego Street, 90-924 tódż, Poland, e-mail: tomasz.szydlowski@p.lodz.pl, ph +48426312395
} 
the solution proposed, a Caterpillar solenoid valve of the high-pressure HEUI (Hydraulically actuated Electronic Unit Injector) system of a diesel engine was used as a distributor and a commercial hydraulic actuator was adapted as the final control element, which forced the engine valve under tests to open. The valve return movement was forced by a typical valve spring. A schematic diagram of the hydraulic part of the valve actuation system has been shown in Fig. 1. It represents a simplified model of hydraulic part of the solenoid valve, hydraulic part of the single-acting actuator, and connecting pipeline.
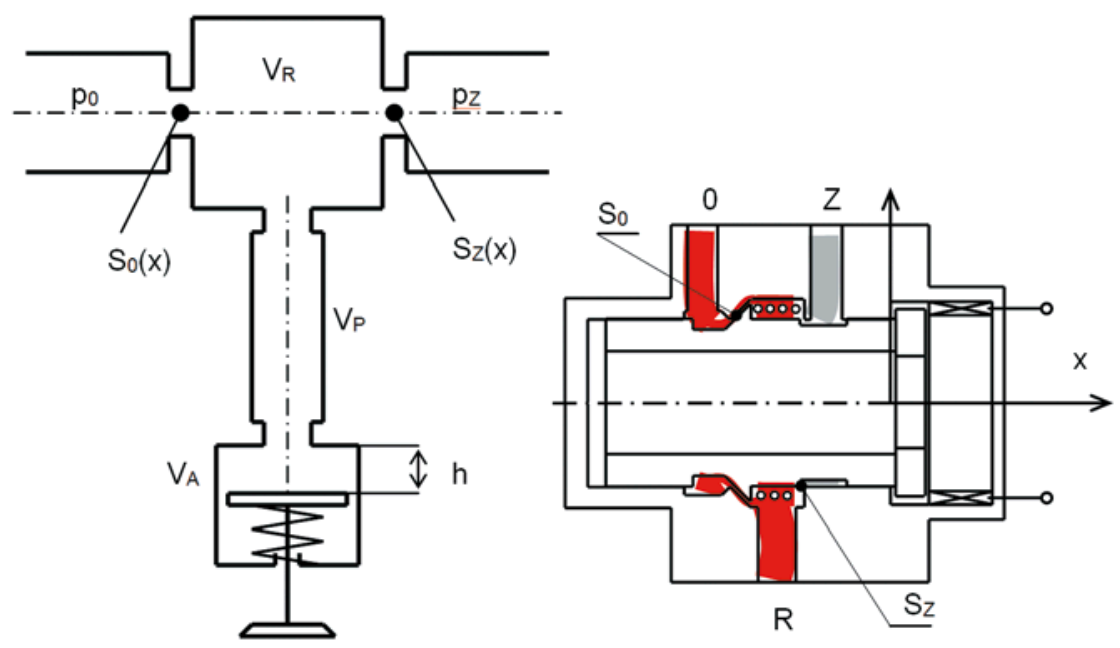

Fig. 1. Schematic diagram of the hydraulic part of the single-acting valve actuation system and the distributor: $\mathrm{x}$ - distributor spool displacement; $\mathbf{h}$ - engine valve displacement; $\mathbf{V}$ - volumes; p- pressures; S - gaps;

Subscripts: P - pipeline; A - actuator; 0 - supply; R - working space; Z - return

When power supply is applied to solenoid terminals, the electromagnet armature moves together with the distributor spool to the right $(x)$ and supply port 0 is connected to outlet port $R$ through working space of $V_{R}$ total volume. Simultaneously, a spool edge cuts off outlet port $\mathrm{R}$ from return port Z. This working position has been shown in Fig. 1. In this position, the supply oil pressure is transmitted to the actuator and the engine valve opens (h). When the distributor solenoid is de-energized, its return spring moves the spool to the left and outlet port $\mathrm{R}$ is cut off from supply port $\mathrm{O}$ and connected with return port $\mathrm{Z}$. Thus, the oil pressure in the actuator drops and the valve spring closes the engine valve.

The necessary mathematical and simulation model of such a valve actuation system was prepared [2,] and a test setup was built for verification, experimental, and simulation test needs, thanks to which the model prepared could be verified. The model thus prepared made it possible to carry out comprehensive simulation tests. 


\section{Simulation tests}

The simulation tests of the model of the single-acting hydraulic drive system with a Caterpillar distributor were carried out in several stages. The parameters of installation and of power and oil supply of a standard distributor in the valve actuation system were checked and analysed and the applicability of such a system to IC piston engines was studied. A question was also examined whether the parameters of operation of the singleacting hydraulic drive system can be significantly improved by a modification of the construction of a standard distributor.

When such a single-acting hydraulic drive system for engine valves is considered, a number of valve motion parameters schematically shown in Fig. 2 and discussed below should be taken into account.

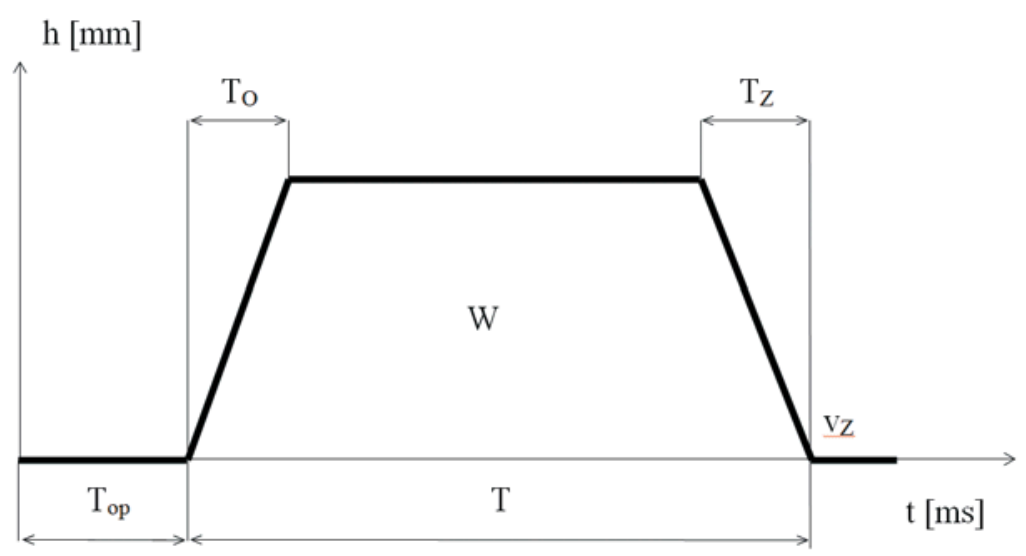

Fig. 2. Valve displacement vs. time curve and valve motion parameters (description in the text)

\section{Delay in the start of the valve motion in relation to the beginning of the control signal, $T_{o p}$}

The delay in the start of the valve motion in relation to the beginning of the control signal (valve actuation delay) consists of the following:

a) Time of applying of forcing current in advance (i.e. time from the applying of the control signal to the start of movement of the solenoid valve spool). During the bench tests, the forcing current was applied in advance by discharging a pre-charged capacitor and this process lasted for about $3 \mathrm{~ms}$.

b) Time from the start of movement of the solenoid valve spool to the beginning of movement of the engine valve (time of building up the necessary actuator pressure).

The total valve actuation delay observed during the bench tests was not shorter than $6 \mathrm{~ms}$ (for an oil supply pressure of $16 \mathrm{MPa}$; at lower oil supply pressures, this delay even exceeded $10 \mathrm{~ms}$ ). For this reason, the engine valve cannot be controlled in real time, after 
the control signal is applied at an instant corresponding to a specific position of the engine crankshaft. The impact of the valve actuation delay on the parameters of operation of the control system has been more comprehensively discussed in paper [3].

\section{Valve opening time, $\mathrm{T}_{0}$}

For high oil supply pressures, of the order of $15 \div 16 \mathrm{MPa}$, a valve opening time of about $2.5 \div 3 \mathrm{~ms}$ was achieved (for a typical valve of a high-speed automotive engine, with $8 \mathrm{~mm}$ nominal valve lift). Al lower oil supply pressures, the valve opening time was significantly longer.

\section{Valve closing time, $T_{z}$}

The valve closing time was constant and remained on a level of about $3 \div 3.5 \mathrm{~ms}$ regardless of the oil supply pressure.

\section{Time of the valve kept open, $\mathrm{T}$, and filling ratio of the area under the valve lift curve, $\mathbf{W}$}

Taking into account the above minimum values of the valve opening and closing time, we may state that full opening of the valve, even with a short period of the valve dwelling in the fully open position, may be achieved if the total time of the valve kept open is about $6.5 \div 7 \mathrm{~ms}$. This corresponds to the motion of a valve driven by a conventional harmonic cam at an engine crankshaft speed of about $6000 \mathrm{rpm}$. The filling ratio of the area under the valve lift curve for a valve train with a conventional harmonic cam is then on a level of $\mathrm{W}=55 \%$. This means that for hydraulically driven valves, lower engine speeds will make it possible to achieve much higher values of the filling ratio, even exceeding $W=90 \%$ for engine speeds below 1500 rpm.

\section{Velocity of the valve hitting its seat, $v_{z}$}

The tests revealed that the valve hit its seat with a high velocity, even of up to $1.5 \mathrm{~m} / \mathrm{s}$. This very high value should be significantly reduced in consideration of limited service life of the system operating in such conditions and of noisy system operation.

\section{Impact of selected parameters of the valve actuation system on system properties}

The impact of various parameters characterizing the construction of the valve actuation system on the valve displacement vs. time curve determined by calculations has been 
discussed below. Time histories obtained from model verification simulation tests at an oil supply pressure of $15 \mathrm{MPa}$ have been selected as the test results to be taken for comparisons.

\section{Impact of oil supply pressure $p_{0}$}

The impact of the oil supply pressure on the properties of the valve actuation system has been shown in Fig. 3. The raising of the oil supply pressure values resulted in insignificant shortening of the valve actuation delay, shortening of the valve opening time, and insignificant increase in the filling ratio of the area under the valve lift curve. On the other hand, higher oil supply pressures produced significant overshoot of the valve displacement following the moment when the maximum valve lift position was reached.

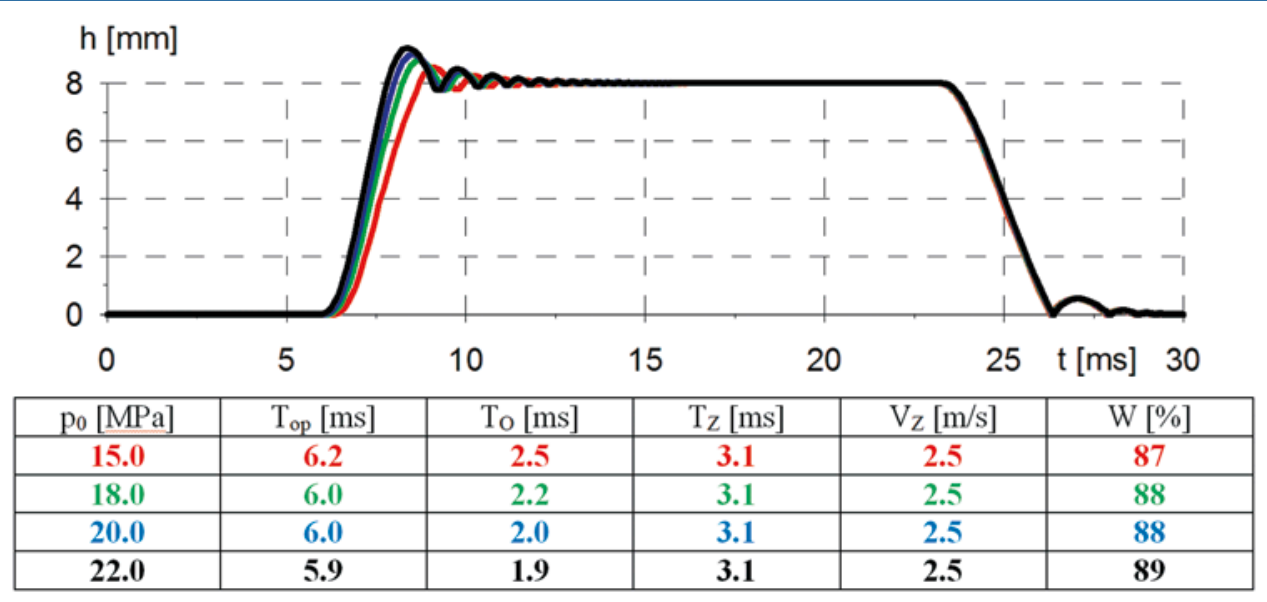

Fig. 3. Impact of the oil supply pressure on the valve displacement vs. time curve

\section{Impact of total working space volume $V_{R}$}

The impact of the total working space volume on the valve displacement vs. time curve has been presented in Fig. 4. When the total working space volume was reduced, the valve actuation delay was significantly shortened. In the valve actuation model having been built, the total working space volume was so large because the test setup was prepared for research purposes and measuring sensors had to be installed in it. In a prototype system version, this volume may be considerably reduced. 


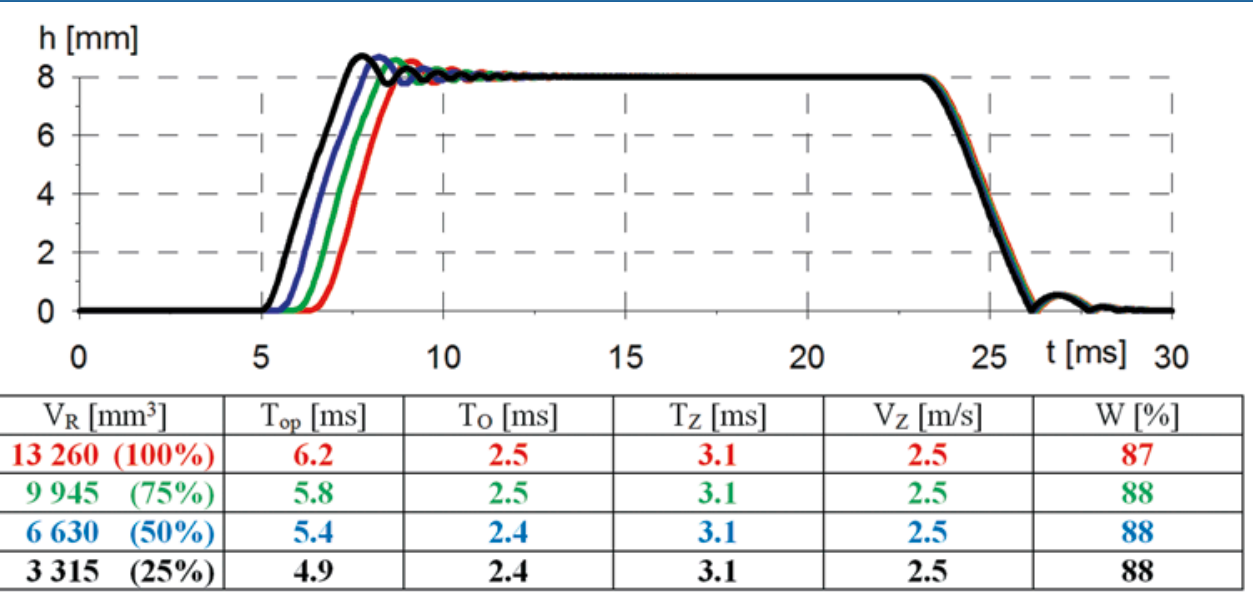

Fig. 4. Impact of the total working space volume on the valve displacement vs. time curve

\section{Impact of power supply voltage $U_{0}$}

The impact of the power supply voltage on the valve displacement vs. time curve has been shown in Fig. 5. Higher power supply voltage values caused significant shortening of the valve actuation delay: due to the applying of forcing current in advance, the current flowing through the distributor solenoid grew with a higher rate and, in consequence, the distributor spool opened much faster.

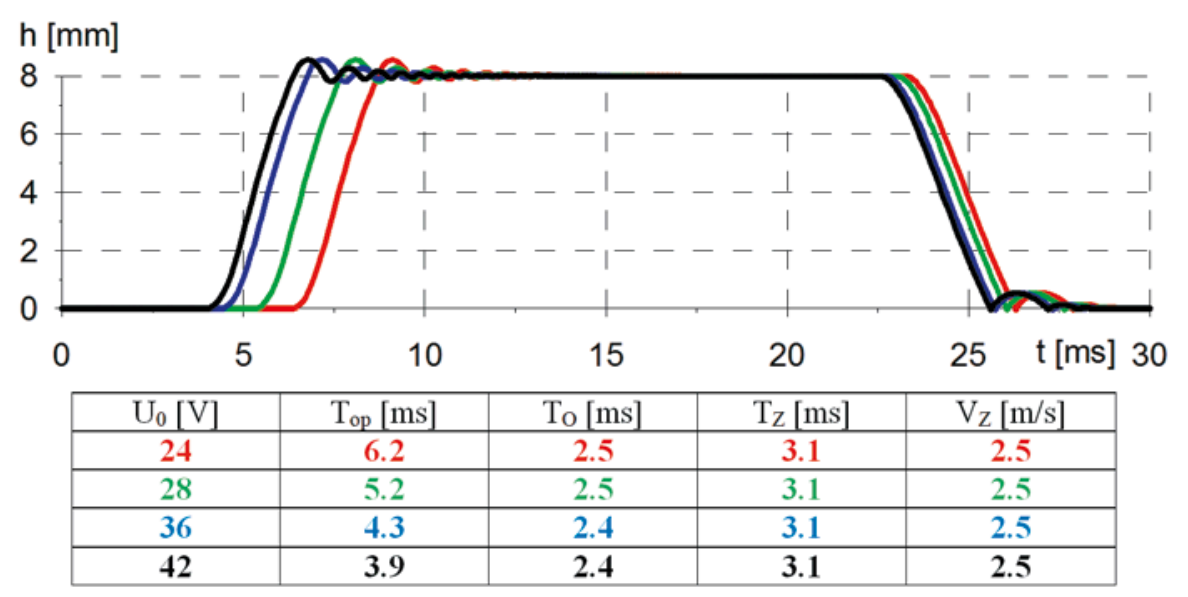

Fig. 5. Impact of the power supply voltage on the valve displacement vs. time curve 


\section{Impact of distributor solenoid force $F_{e}$}

The impact of the distributor solenoid force on the valve displacement vs. time curve has been illustrated in Fig. 6. Increased distributor solenoid efficiency produced a reduction in the valve actuation delay by causing the distributor spool movement to be faster.

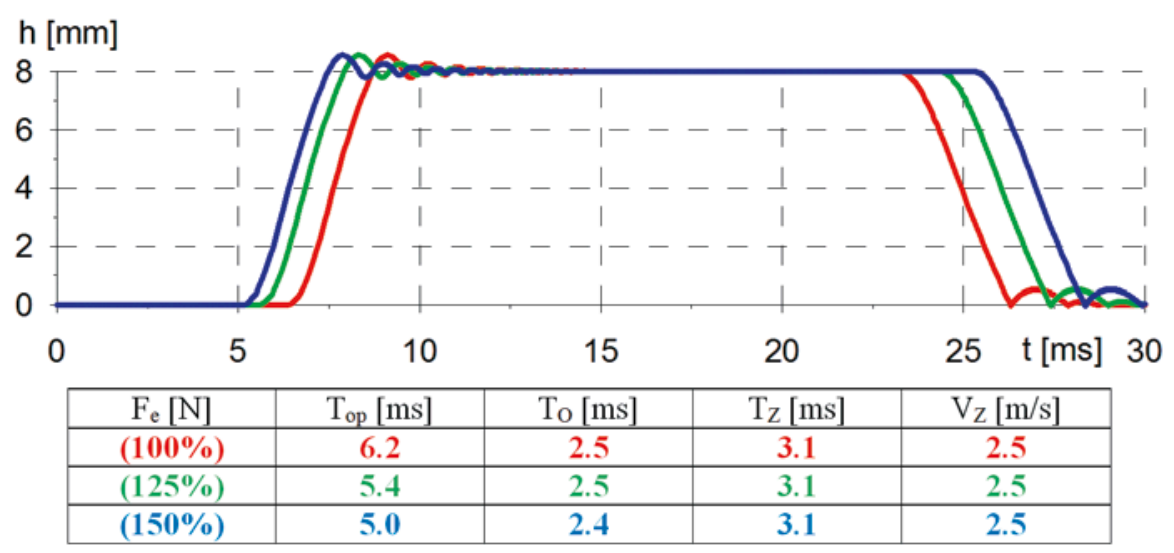

Fig. 6. Impact of the distributor solenoid force on the valve displacement vs. time curve

\section{Impact of total distributor spool and armature mass $\mathbf{m}_{\mathrm{s}}$}

The impact of the total mass of moving distributor parts such as spool and electromagnet armature was almost imperceptible, even when this mass was reduced to about $50 \%$.

\section{Impact of engine valve mass $\mathrm{m}_{\mathrm{z}}$}

The impact of the engine valve mass on the valve displacement vs. time curve was negligible; even if the mass were reduced to about $70 \%$, e.g. by using valves made of titanium, the difference would be indiscernible. This impact chiefly manifested itself in the phase of the valve hitting its seat and it can only be noticed in the case of large and heavy valves.

\section{Impact of distributor supply gap cross-section $\mathbf{S}_{0}$}

The impact of the distributor supply gap cross-section on the valve displacement vs. time curve has been presented in Fig. 7. Widening of the distributor supply gap resulted in significant reductions in the valve actuation delay and in the valve opening time. On the other hand, it produced very big overshoot of the valve displacement following the moment when the maximum valve lift position was reached. In addition to this, extensive modification to the distributor design would be required to increase the rate of oil flow through the distributor supply gap. 


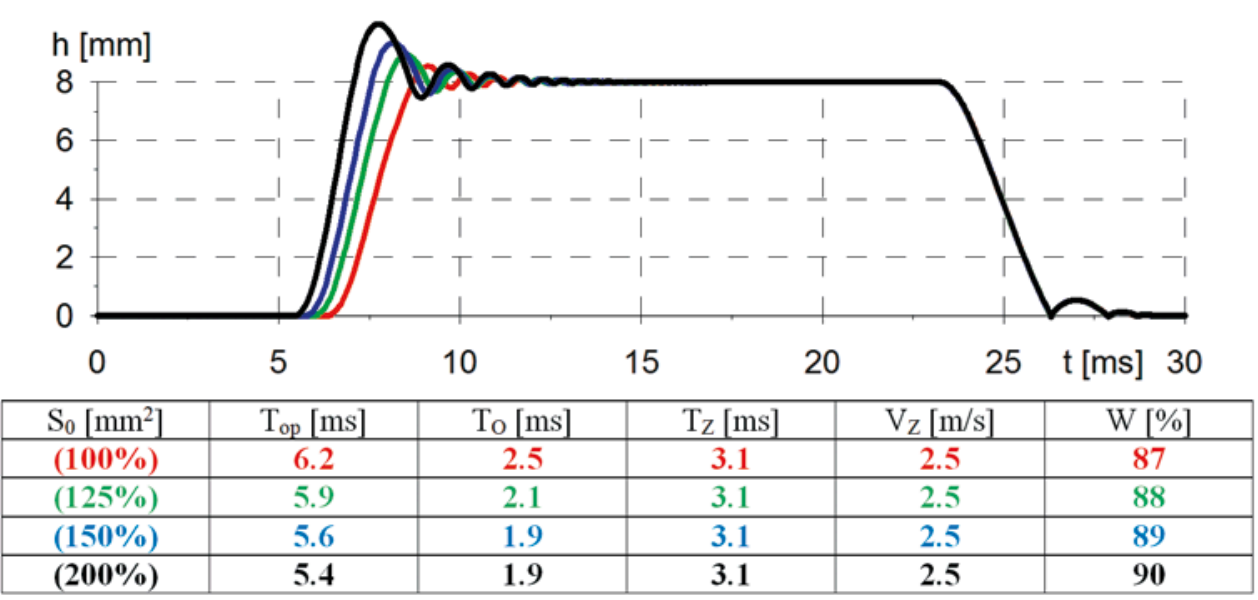

Fig. 7. Impact of the distributor supply gap cross-section on the valve displacement vs. time curve

\section{Impact of distributor overflow gap cross-section $\mathrm{S}_{\mathrm{z}}$}

The impact of the distributor overflow gap cross-section on the valve displacement vs. time curve has been presented in Fig. 8. Reductions in the distributor overflow gap crosssection resulted in extended valve closing time, lowered velocity of the valve hitting its seat, and reduced filling ratio of the area under the valve lift curve. The lowering of the valve impact velocity would obviously be a favourable effect of a possible modification to the distributor; however, this would simultaneously entail prolongation of the valve closing time and, in consequence, reduction of the filling ratio of the area under the valve lift curve.

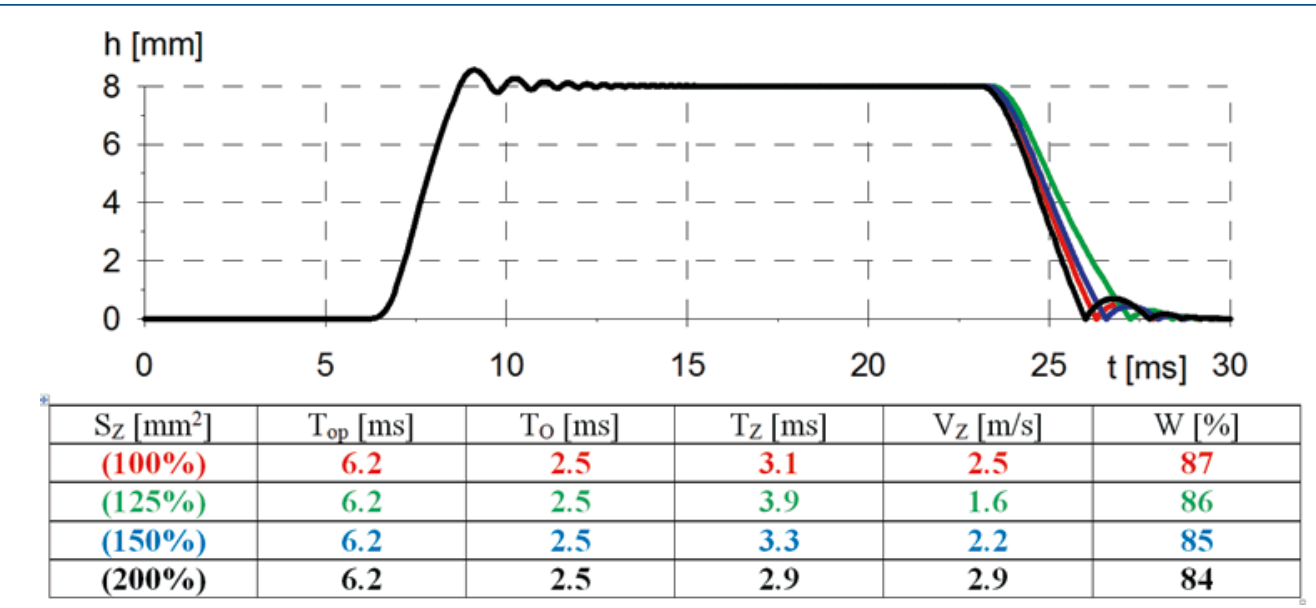

Fig. 8. Impact of the distributor overflow gap cross-section on the valve displacement vs. time curve 


\section{Impact of hydraulic actuator piston diameter d}

The impact of the hydraulic actuator piston diameter on the valve displacement vs. time curve has been presented in Fig. 8 and in Table 1.

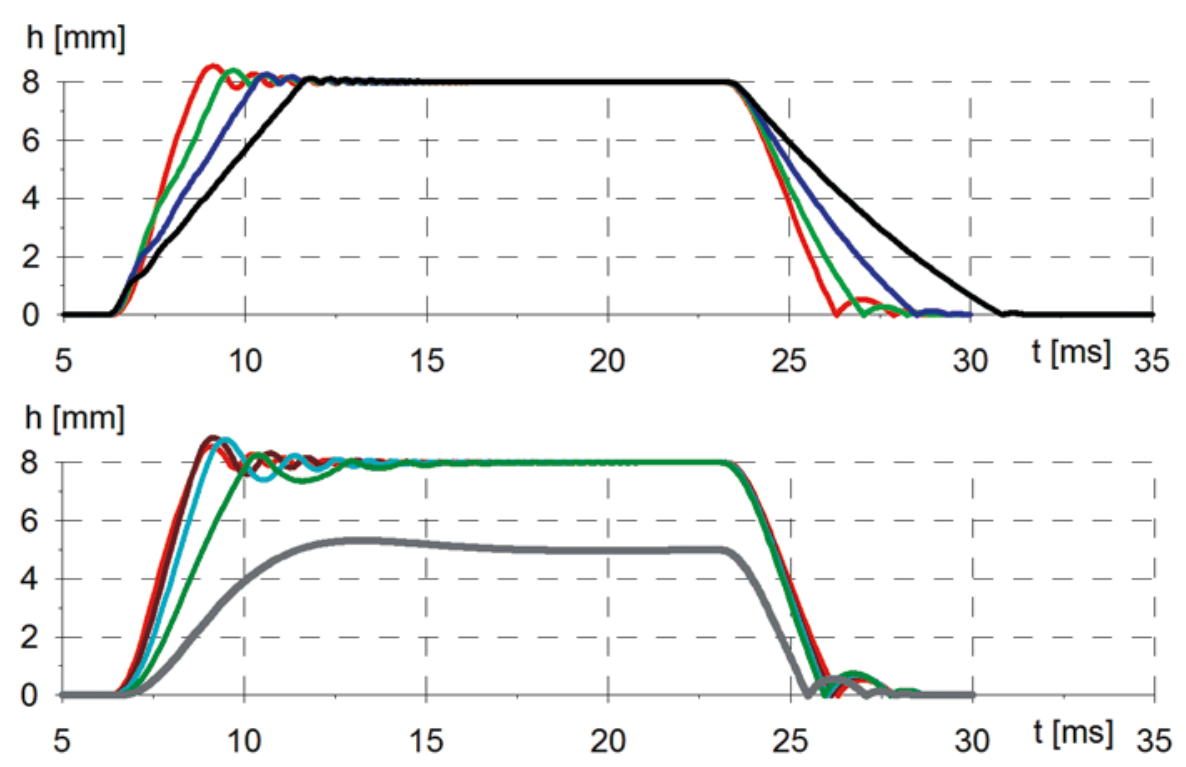

Fig. 9. Impact of the hydraulic actuator piston diameter on the valve displacement vs. time curve

Table 1. Impact of the hydraulic actuator piston diameter on the valve motion parameters

\begin{tabular}{|c|c|c|c|c|}
\hline $\mathrm{d}[\mathrm{mm}]$ & $\mathrm{T}_{\text {op }}[\mathrm{ms}]$ & $\mathrm{T}_{\mathrm{O}}[\mathrm{ms}]$ & $\mathrm{T}_{\mathrm{Z}}[\mathrm{ms}]$ & $\mathrm{V}_{\mathrm{Z}}[\mathrm{m} / \mathrm{s}]$ \\
\hline 4.0 & & & & \\
\hline $\mathbf{5 . 0}$ & $\mathbf{6 . 3}$ & 3.8 & 2.9 & 3.1 \\
\hline 6.0 & 6.3 & 2.7 & 2.9 & 3.0 \\
\hline 7.0 & 6.2 & 2.4 & 3.0 & 2.8 \\
\hline 8.0 & 6.2 & 2.5 & 3.1 & 2.5 \\
\hline 10.0 & 6.2 & 3.1 & 3.8 & 1.7 \\
\hline 12.0 & $\mathbf{6 . 2}$ & $\mathbf{4 . 1}$ & $\mathbf{5 . 3}$ & 1.1 \\
\hline $\mathbf{1 4 . 0}$ & $\mathbf{6 . 2}$ & $\mathbf{5 . 4}$ & $\mathbf{7 . 6}$ & $\mathbf{0 . 9}$ \\
\hline
\end{tabular}

Enlargement of the hydraulic actuator piston diameter translates into significant increase in the actuator chamber absorbing capacity. In the case under consideration, this resulted in extended valve opening and closing time and reduced filling ratio of the area under the valve lift curve. This impact is particularly noticeable for the actuator diameters exceeding $10 \mathrm{~mm}$. The only favourable effect of such a modification was the fact that the velocity of the valve hitting its seat was thus significantly lowered. 
Based on an analysis of the results obtained, a statement may be made that neither enlargement nor reduction of the actuator diameter improved the performance of the valve actuation system. Due to low working medium flow capacity even at high supply pressures, the Caterpillar distributor is unsuitable for larger hydraulic actuators. On the other hand, actuators with smaller piston diameters do not produce adequate valve actuation force.

\section{Impact of initial valve spring deflection $y_{0}$}

The impact of the initial valve spring deflection on the valve displacement vs. time curve has been illustrated in Fig. 10. On the one hand, bigger initial deflection of the valve spring prolonged the valve actuation delay and valve opening time; on the other hand, it resulted in shorter valve closing time and higher velocity of the valve hitting its seat. Simultaneously, the filling ratio of the area under the valve lift curve did not change, due to opposite impacts of the initial valve spring deflection on the valve opening and closing phase. This parameter may only be changed within a narrow range because of the spring strength characteristics.

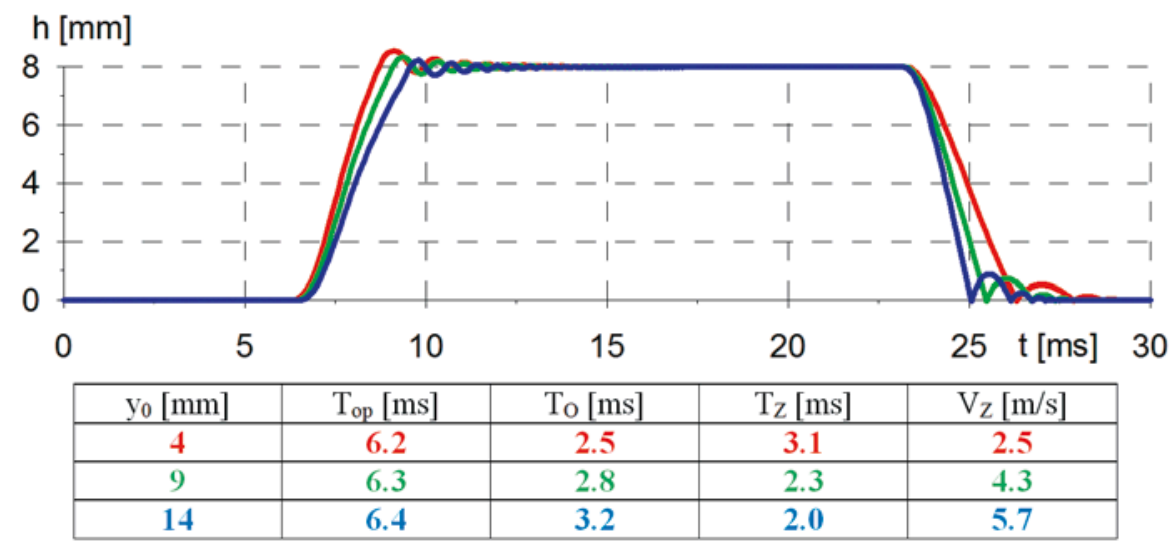

Fig. 10. Impact of the initial valve spring deflection on the valve displacement vs. time curve

\section{Impact of valve spring rate $k$}

The impact of the valve spring rate on the valve displacement vs. time curve has been illustrated in Fig. 11. On the one hand, increasing values of the valve spring rate prolonged the valve actuation delay and valve opening time; on the other hand, it resulted in shorter valve closing time and much higher velocity of the valve hitting its seat. Simultaneously, the filling ratio of the area under the valve lift curve only slightly increased, due to opposite impacts of the valve spring rate on the valve opening and closing phase. It seems justified to hazard an opinion that the use of valve springs with as high a spring rate value as practicable would be most advantageous for the valve actuation system; additionally, such a solution would raise the spring resonance frequency value. 


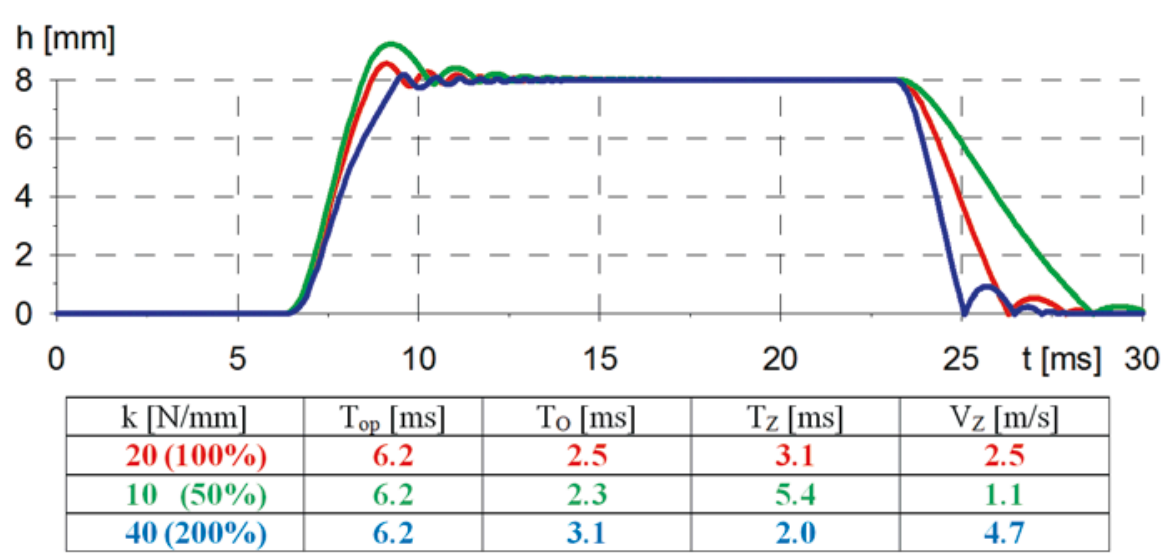

Fig. 11. Impact of the valve spring rate on the valve displacement vs. time curve

\section{Impact of valve spring characteristic curve}

The impact of the valve spring characteristic curve on the valve displacement vs. time curve has been illustrated in Fig. 12. Within the simulation tests, the valve train provided with a valve spring of stepwise-changing rate was examined. For the valve displacement range exceeding $75 \%$ of the maximum valve lift, the valve spring rate was raised stepwise. The variable spring rate did not result in a significant change in the valve opening time; on the other hand, the undesirable phenomenon of temporary loss of contact between the actuator piston rod and the valve stem could be thus reduced. Moreover, rising values of the spring rate increment (dk) in the final valve displacement phase resulted in reductions in the valve closing time, which favourably affected the filling ratio of the area under the valve lift curve.

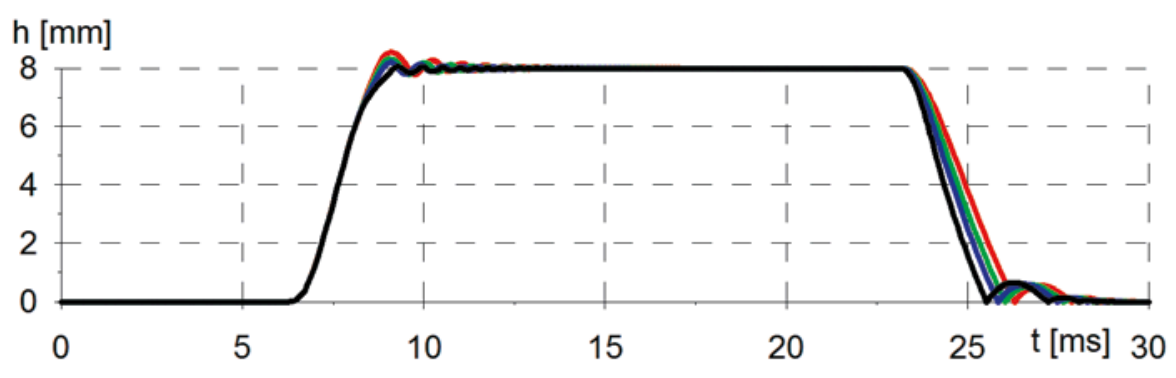

\begin{tabular}{|c|c|c|c|c|}
\hline $\mathrm{dk}[\mathrm{N} / \mathrm{mm}]$ & $\mathrm{T}_{\mathrm{op}}[\mathrm{ms}]$ & $\mathrm{T}_{\mathrm{O}}[\mathrm{ms}]$ & $\mathrm{T}_{\mathrm{Z}}[\mathrm{ms}]$ & $\mathrm{V}_{\mathrm{Z}}[\mathrm{m} / \mathrm{s}]$ \\
\hline$+(\mathbf{0} \%)$ & 6.2 & 2.5 & 3.1 & 2.5 \\
\hline$+(25 \%)$ & 6.2 & 2.6 & 2.9 & 2.5 \\
\hline$+(\mathbf{5 0} \%)$ & 6.2 & 2.6 & 2.7 & 2.6 \\
\hline
\end{tabular}

Fig. 12. Impact of the valve spring characteristic curve on the valve displacement vs. time curve 


\section{Recapitulation}

The paper presents results of simulation examination of the properties of a single-acting electrohydraulic system built to actuate an IC engine valve. The information gained from the testing of such a system has made it possible to determine the basic properties of the valve actuation system type under investigation and to formulate engineering guidelines and recommendations, which is important from the point of view of further work aimed at the development of a prototype electrohydraulic system of actuation of an engine valve.

The material presented provides grounds for determining the impact of selected parameters of an electrohydraulic system actuating an IC engine valve on the properties of such a system. Thanks to the tests carried out, the most important conclusions may be formulated as follows:

- Due to low working medium flow capacity, the Caterpillar distributor is unsuitable for systems intended to actuate larger engine valves; it may only be used for the actuation of small valves of high-speed automotive engines.

- For the valve actuation delay and the limited valve opening velocity to be compensated, feedback control systems must be used so that the control signal is generated appropriately in advance in relation to the required valve opening instant.

- To enable the use of valve actuation systems of this type in high-speed engines, relatively high oil supply pressures must be applied, even of about $20 \mathrm{MPa}$; moreover, the power supply voltage should be as high as possible and a system of applying forcing current in advance to open the distributor should also be provided.

- For high-speed engine applications, a special design of the distributor installation is necessary in order to minimize the total volume of the working space, which includes the actuator working chamber and the connecting pipes; probably, the distributor should be directly installed on the hydraulic actuator.

- For the engine valve actuation system of the type under consideration to be used in a wider range of applications, the distributor should be modified so that the solenoid efficiency is increased and its electromagnetic force is thus raised and so that the cross-section of the distributor supply gap is enlarged.

The detailed analyses presented in this paper may provide a basis for further research on the hydraulic drives for IC engine valves. 


\section{References}

[1] BARROS da CUNHA S., HEDRICK K., PISANO A.: Variable Valve Timing By Means of a Hydraulic Actuation. Society of Automotive Engineers 2000, SP-1523.

[2] SMOCZYŃSKI, M., SZYDŁOWSKI, T.: Model of Hydraulic Single-acting Drive for Valves of Internal Combustion Engines. Journal of KONES: Powertrain and Transport, Vol. 16, No. 1, pp. 465 472, 2009.

[3] ZBIERSKI, K., SMOCZYŃSKI, M.: Motion Properties of Hydraulically Actuated Valve Train. Journal of KONES:

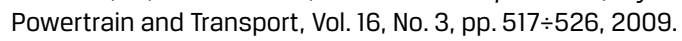

[4] ZBIERSKI, K.: Koncepcja i bezsilnikowe badania bezkrzywkowego elektrohydraulicznego rozrządu tłokowego silnika spalinowego (Conception and Initial Researches of Electrohydraulic Valve Timing for Internal Combustion Engine). Journal of Internal Combustion Engines, Kones 2006, Nałęczów 2006. 


\title{
BADANIA WLAŚCIWOŚCI HYDRAULICZNEGO NAPEDU JEDNOSTRONNEGO DZIALANIA DLA ZAWORÓW SILNIKOWYCH
}

\author{
MARIUSZ SMOCZYŃSKI', TOMASZ SZYDŁOWSKI² \\ Politechnika Łódzka
}

\section{Streszczenie}

W artykule opisano badania właściwości hydraulicznego napędu jednostronnego działania dla zaworów rozrządu tłokowego silnika spalinowego. W proponowanym napędzie jako rozdzielacz wykorzystano elektrozawór Caterpillar z systemu HEUI. Jako element wykonawczy zastosowano komercyjny siłownik hydrauliczny. Badania przeprowadzono dla przygotowanego modelu takiego napędu. Analizowano wpływ różnych parametrów konstrukcyjnych na przebieg wzniosu zaworu oraz jego charakterystyczne parametry: opóźnienie rozpoczęcia ruchu zaworu w stosunku do początku sygnału sterującego, czas otwierania i zamykania zaworu, czas otwarcia zaworu, przebieg wzniosu zaworu, wskaźnik wypełnienia pola pod krzywą wzniosu oraz prędkość osiadania zaworu w gnieździe. Jako parametry konstrukcyjne takiego napędu szczegółowo przeanalizowano: ciśnienie zasilania, objętość komory roboczej, napięcie zasilania, siłę elektromagnesu rozdzielacza, przekrój szczeliny zasilającej i przelewowej, masy części ruchomych rozdzielacza, masę zaworu, średnicę tłoka siłownika hydraulicznego oraz charakterystykę sprężyny zaworowej. Wykazano konieczność stosowania dużych ciśnień zasilających oraz dużych napięć sterujących. Podano wytyczne do konstrukcji napędu takiego typu. Wykazano, że ze względu na niewielki wydatek rozdzielacze takiego typu nadają się tylko do napędu małych zaworów szybkoobrotowych silników spalinowych. Dowiedziono, że ze względu na zwłokę zadziałania oraz szybkość otwierania zaworu konieczne jest stosowanie układów wypracowujących wyprzedzenie sygnału sterującego w stosunku do żądanej chwili otwarcia zaworu. Zwrócono także uwagę na stosunkowo dużą możliwość kształtowania przebiegu krzywej wzniosu zaworu.

Słowa kluczowe: silnik spalinowy, bezkrzywkowy napęd zaworów, napęd hydrauliczny

\section{Wprowadzenie}

Podczas prac prowadzonych nad rozrządem hydraulicznym tłokowych silników spalinowych przebadano, jako jeden z możliwych, hydrauliczny napęd jednostronnego działania

\footnotetext{
'Politechnika Łódzka, Katedra Pojazdów i Podstaw Budowy Maszyn, ul. Żeromskiego 116, 90-924 tódż, Polska, e-mail: mariusz.smoczynski@p.lodz.pl, tel. 426312390

2 Politechnika Łódzka, Katedra Pojazdów i Podstaw Budowy Maszyn, ul. Żeromskiego 116, 90-924 Łódż, Polska, e-mail: tomasz.szydlowski@p.lodz.pl, tel. 426312395
} 
$[1,4]$. W proponowanym napędzie jako rozdzielacz wykorzystano elektrozawór Caterpillar z systemu HEUI - element wysokociśnieniowego pompowtryskiwacza dla silnika o zapłonie samoczynnym [3]. Jako element wykonawczy wymuszający otwarcie zaworu silnikowego zastosowano komercyjny siłownik hydrauliczny. Ruch powrotny zaworu wymuszała typowa sprężyna zaworowa. Na rysunku 1 pokazano schemat hydraulicznej części napędu. Zawiera ona uproszczony model części hydraulicznej elektrozaworu, część hydrauliczną siłownika jednostronnego działania oraz przewód łączący.
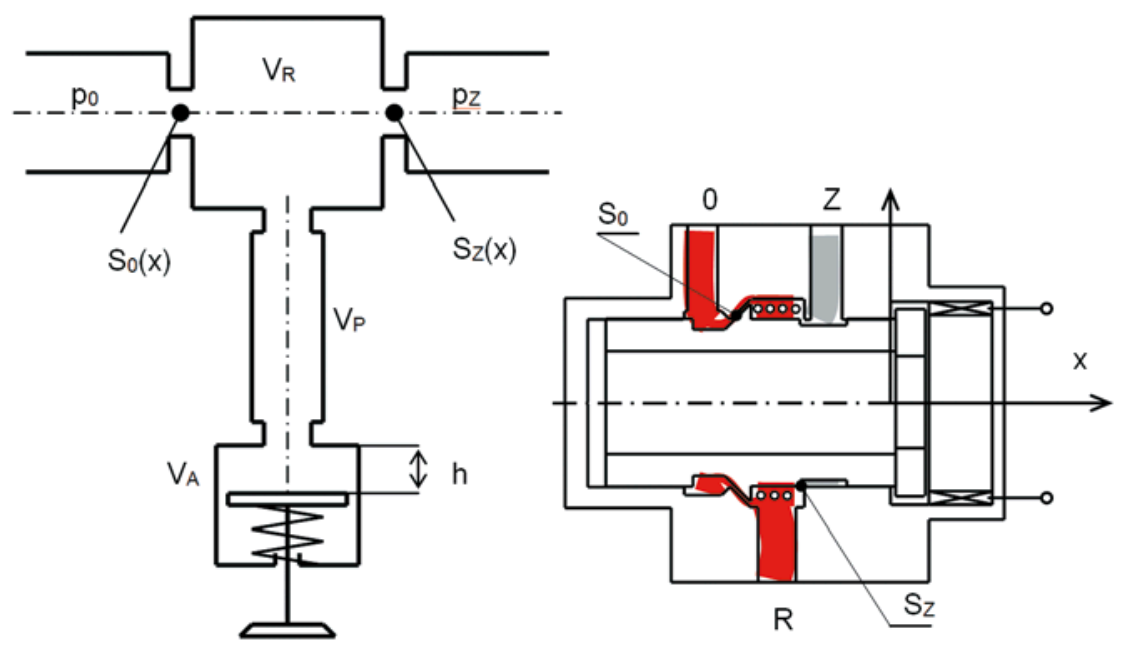

Rys. 1. Schemat hydraulicznej części napędu jednostronnego działania oraz rozdzielacza: $\mathrm{x}$ - przemieszczenie suwaka rozdzielacza, $\mathbf{h}$ - przemieszczenie zaworu silnikowego, V - objętości, p - ciśnienia, S - szczeliny, indeksy: P - przewód, A - siłownik, 0 - zasilanie, $\mathrm{R}$ - komora robocza, Z - powrót

Po włączeniu napięcia sterującego na zaciski cewki elektromagnesu, następuje przesunięcie zwory wraz z suwakiem $\mathrm{w}$ prawo $(\mathrm{x})$ i połączenie kanału zasilającego $\mathrm{O}$ z kanałem wylotowym $R$ przez komorę roboczą o objętości $V_{R^{*}}$. Jednocześnie krawędź suwaka odcina kanał wylotowy R od kanału powrotnego Z. Ta pozycja pracy (zawór sterujący otwarty) została pokazana na rysunku 1. W tej pozycji ciśnienie oleju zasilającego jest przekazywane do siłownika i zawór silnikowy otwiera się (h). Po zaniku napięcia zasilającego cewkę sprężyna powrotna przesuwa suwak w lewo, odcina kanał wylotowy R od kanału zasilającego 0 i jednocześnie łączy kanał wyjściowy $R$ z kanałem powrotnym Z. W ten sposób zmniejszane jest ciśnienie w elemencie roboczym i sprężyna zaworowa zamyka zawór silnika.

Przygotowano niezbędny model matematyczny i symulacyjny takiego napędu [2]. Dla potrzeb badań weryfikacyjnych, eksperymentalnych oraz symulacyjnych zbudowano stanowisko badawcze, które umożliwiło sprawdzenie przygotowanego modelu. Tak przygotowany model umożliwił przeprowadzenie szerokich badań symulacyjnych. 


\section{Badania symulacyjne}

Badania symulacyjne modelu hydraulicznego napędu jednostronnego działania wykorzystującego rozdzielacz Caterpillar wykonano w kilku etapach. Sprawdzono i przeanalizowano parametry zabudowy i zasilania standardowego rozdzielacza w napędzie oraz przeanalizowano możliwości jego zastosowania w tłokowych silnikach spalinowych. Sprawdzono, czy możliwa jest znacząca poprawa parametrów pracy napędu jednostronnego działania poprzez modyfikację konstrukcji standardowego rozdzielacza.

Rozważając taki hydrauliczny układ napędu zaworów jednostronnego działania należy wziąć pod uwagę kilka parametrów ruchu zaworu pokazanych schematycznie na rysunku 2 i omówionych poniżej.

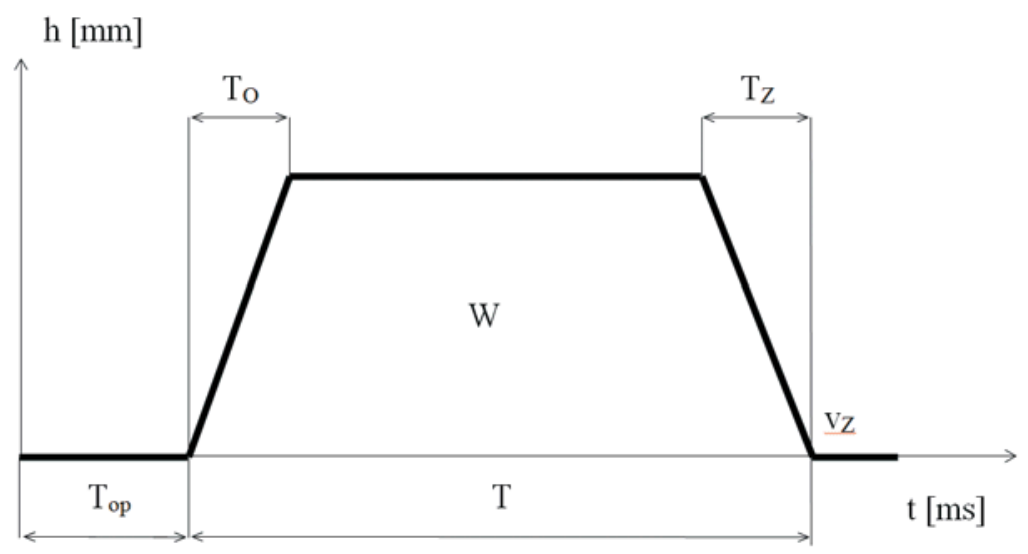

Rys. 2. Przebieg wzniosu i parametry ruchu zaworu (opis w tekście)

\section{Opóżnienie rozpoczęcia ruchu zaworu w stosunku do początku sygnału sterującego $\mathrm{T}_{\mathrm{op}}$}

Na czas opóźnienia rozpoczęcia ruchu zaworu w stosunku do początku sygnału sterującego (zwłokę zadziałania napędu) składają się:

a) czas forsowania prądem (czas od chwili podania sygnału sterującego do rozpoczęcia ruchu suwaka). W trakcie badań stanowiskowych forsowanie odbywało się poprzez rozładowanie uprzednio naładowanego kondensatora i trwało około 3 ms;

b) czas od rozpoczęcia ruchu suwaka do początku ruchu zaworu (czas narastania ciśnienia w siłowniku).

Łączna czas zwłoki zadziałania napędu stwierdzony podczas badań stanowiskowych nie był mniejszy niż 6 ms (dla ciśnienia zasilania $16 \mathrm{MPa}$ ), a przy mniejszych ciśnieniach zasilania osiągał wartość nawet ponad $10 \mathrm{~ms}$. 
Z tego powodu sterowanie zaworem nie może odbywać się w czasie rzeczywistym, po podaniu sygnału sterującego w chwili odpowiadającej jednemu położeniu wału korbowego silnika. Szerzej wpływ zwłoki zadziałania napędu na parametry układu sterowania omówiono w artykule [3].

\section{Czas otwierania zaworu $\mathrm{T}_{0}$}

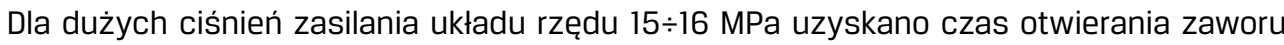
wynoszący około 2,5 $\div 3$ ms (dla typowego zaworu szybkoobrotowego silnika samochodowego o wzniosie $8 \mathrm{~mm}$ ). Mniejsze ciśnienia zasilania powodowały znaczące zwiększenie czasu otwierania zaworu.

\section{Czas zamykania zaworu $\mathrm{T}_{\mathrm{z}}$}

Czas zamykania zaworu był stały i wynosi około $3 \div 3,5$ ms niezależnie od ciśnienia zasilania.

\section{Czas otwarcia Ti wskaźnik wypełnienia pola pod krzywą wzniosów W}

Uwzględniając wyżej wymienione minimalne czasy otwarcia i zamknięcia zaworu można stwierdzić, że możliwe jest osiąganie pełnych otwarć zaworu, nawet z krótkim jego przestojem w maksymalnym położeniu, w czasach otwarcia wynoszących około 6,5 $\div$ ms. Odpowiada to ruchowi zaworu napędzanego klasyczną krzywką harmoniczną przy prędkości obrotowej silnika około 6000 obr/min. Wskaźnik wypełnienia pola pod krzywą wzniosów dla rozrządu napędzanego klasyczną krzywką harmoniczną kształtuje się wtedy na poziomie $\mathrm{W}=55 \%$. Zatem w przypadku napędu hydraulicznego mniejsze prędkości obrotowe silnika pozwolą na uzyskiwanie znacznie większych wartości wskaźnika napełnienia, przekraczających nawet $\mathrm{W}=90 \%$ dla prędkości mniejszych od 1500 obr/min.

\section{Prędkość osiadania zaworu w gnieździe $\mathrm{V}_{\mathrm{z}}$}

Podczas badań stwierdzono dużą prędkość osiadania zaworu w gnieździe wynoszącą nawet 1,5 m/s. Tak duża prędkość powinna być znacznie zredukowana, ze względu na ograniczoną żywotność tak pracującego układu oraz dużą jego hałaśliwość.

\section{Wpływ wybranych parametrów napędu na jego właściwości}

Poniżej omówiono wpływ różnych parametrów charakteryzujących konstrukcję napędu na uzyskiwany podczas obliczeń przebieg wzniosu zaworu. Jako wyniki do porównań 
wybrano przebiegi badań symulacyjnych dla ciśnienia zasilania 15 MPa uzyskane podczas weryfikacji modelu.

\section{Wpływ ciśnienia zasilania $p_{0}$}

Wpływ ciśnienia zasilania na właściowości napędu pokazano na rysunku 3. Zwiększenie wartości ciśnienia zasilania powoduje nieznaczne skrócenia czasu zwłoki zadziałania napędu, skrócenie czasu otwierania zaworu oraz nieznaczny wzrost wypełnienia pola pod wzniosem zaworu. Większe ciśnienie zasilania zwiększa znacząco przesterowanie zaworu po osiągnięciu przez niego maksymalnego wzniosu.

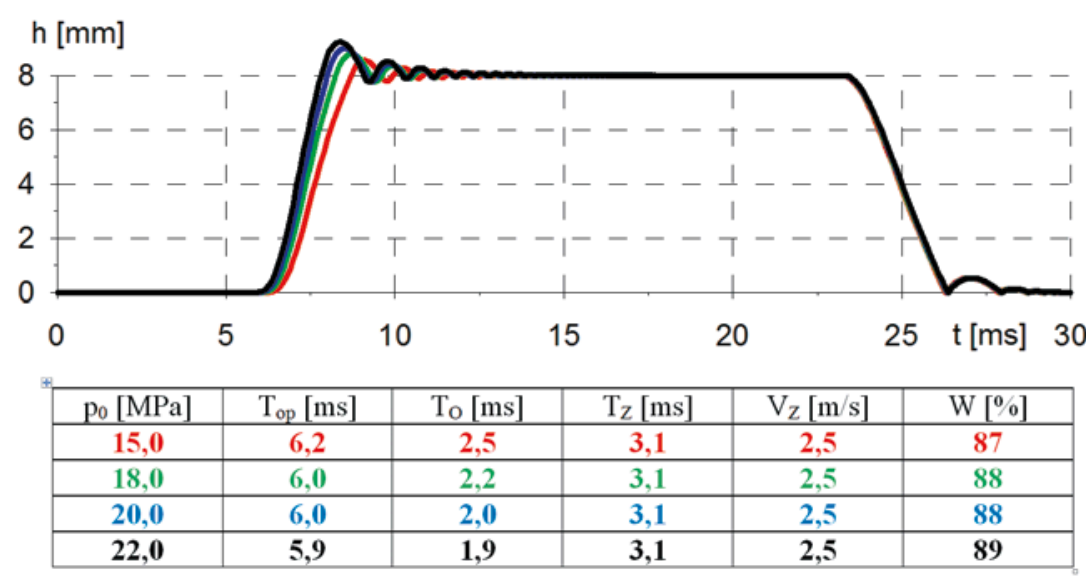

Rys. 3. Wpływ ciśnienia zasilania na przebieg wzniosu zaworu

\section{Wpływ objętości komory roboczej $V_{R}$}

Wypływ wielkości objętości komory roboczej na przebiegi wzniosu zaworu przedstawiono na rysunku 4. Zmniejszenie objętości komory roboczej skraca znaczne czas zwłoki zadziałania napędu. W zbudowanym modelowym napędzie duża objętość komory wynikła z badawczego charakteru stanowiska i konieczności zamocowania czujników pomiarowych. W konstrukcji prototypowej możliwe jest znaczne jej zmniejszenie. 


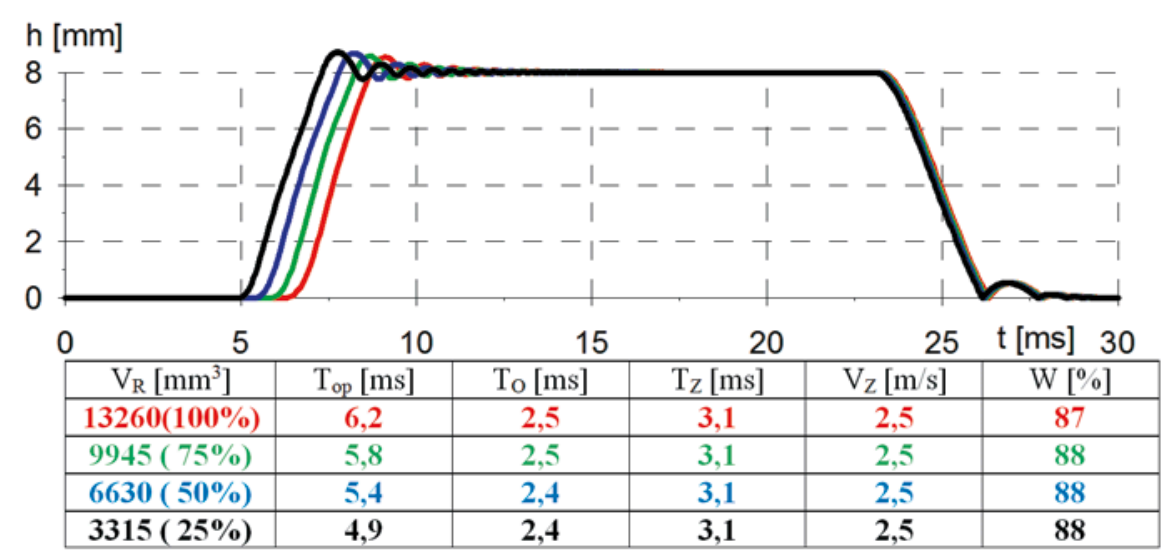

Rys. 4. Wpływ objętości komory roboczej na przebieg wzniosu zaworu

\section{Wypływ napięcia zasilania $U_{0}$}

Wpływ napięcia zasilania na przebieg wzniosu zaworu przedstawiono na rysunku 5. Zwiększenie napięcia zasilania powoduje istotne skrócenie czasu zwłoki zadziałania napędu, ze względu na forsowanie prądem - szybszy wzrost natężenia prądu płynącego przez cewkę rozdzielacza i w konsekwencji znacznie szybsze otwieranie suwaka rozdzielacza.

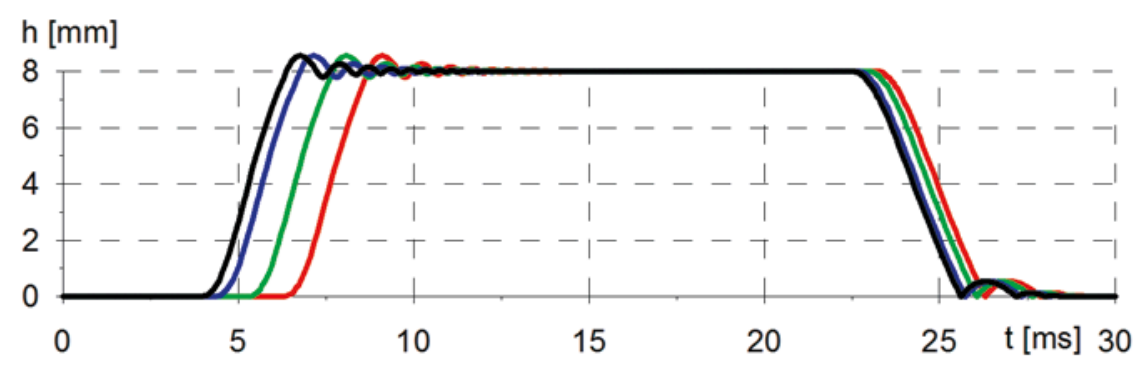

\begin{tabular}{|c|c|c|c|c|}
\hline $\mathrm{U}_{0}[\mathrm{~V}]$ & $\mathrm{T}_{\text {op }}[\mathrm{ms}]$ & $\mathrm{T}_{\mathrm{O}}[\mathrm{ms}]$ & $\mathrm{T}_{Z}[\mathrm{~ms}]$ & $\mathrm{V}_{\mathrm{Z}}[\mathrm{m} / \mathrm{s}]$ \\
\hline 24 & 6,2 & 2,5 & 3,1 & 2,5 \\
\hline 28 & 5,2 & 2,5 & 3,1 & 2,5 \\
\hline 36 & $\mathbf{4 , 3}$ & 2,4 & 3,1 & 2,5 \\
\hline $\mathbf{4 2}$ & $\mathbf{3 , 9}$ & $\mathbf{2 , 4}$ & $\mathbf{3 , 1}$ & $\mathbf{2 , 5}$ \\
\hline
\end{tabular}

Rys. 5. Wpływ napięcia zasilania na przebieg wzniosu zaworu 


\section{Wpływ siły elektromagnesu rozdzielacza $F_{e}$}

Wpływ siły elektromagnesu na przebieg wzniosu zaworu przedstawiono na rysunku 6. Zwiększenie sprawności elektromagnesu rozdzielacza spowoduje zmniejszenie zwłoki zadziałania poprzez szybszy ruch suwaka rozdzielacza.

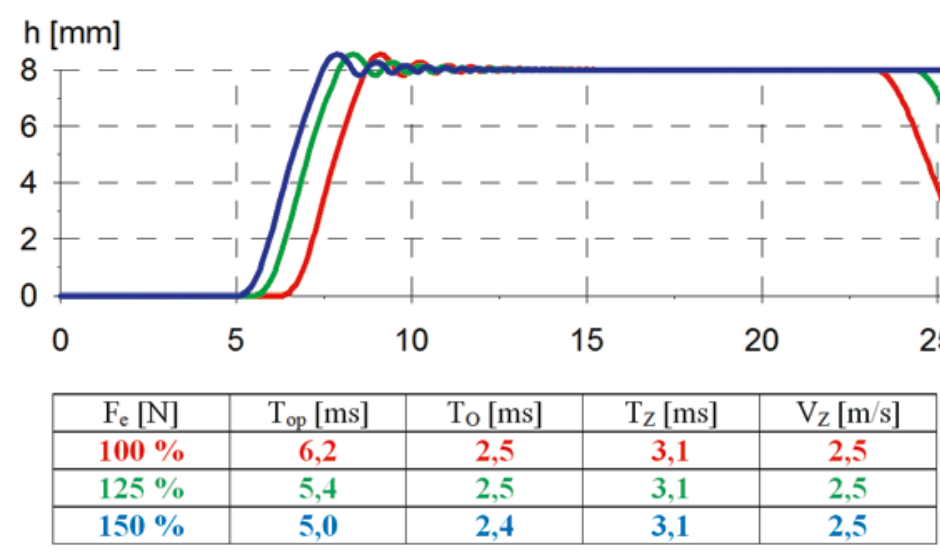

Rys. 6. Wpływ siły elektromagnesu rozdzielacza na przebieg wzniosu zaworu

\section{Wpływ masy suwaka i zwory rozdzielacza $\mathrm{m}_{\mathrm{s}}$}

Wpływ masy części ruchomych rozdzielacza: suwaka i zwory elektromagnesu jest prawie niezauważalny, nawet przy zmniejszeniu tej masy do około 50\%.

\section{Wpływ masy zaworu $\mathrm{m}_{\mathrm{z}}$}

Wpływ masy zaworu na jego wznios jest minimalny, nawet przy zmniejszeniu tej masy do około 70\% - np. dzięki zastosowaniu zaworów tytanowych. Dotyczy on głównie fazy uderzania zaworu o gniazdo i może być zauważalny dla dużych i ciężkich zaworów.

\section{Wpływ szczeliny zasilającej rozdzielacza $S_{0}$}

Wpływ wielkości szczeliny zasilającej na przebieg wzniosu zaworu przedstawiono na rysunku 7. Zwiększenie szczeliny zasilającej rozdzielacza powoduje znaczne skrócenie czasu zwłoki zadziałania napędu oraz zmniejszenie czasu otwierania zaworu. Zwiększa jednak znacząco przesterowanie zaworu po osiągnięciu przez niego maksymalnego wzniosu. Zwiększenie przepływu przez szczelinę zasilającą wymaga jednak poważnej modyfikacji rozdzielacza. 


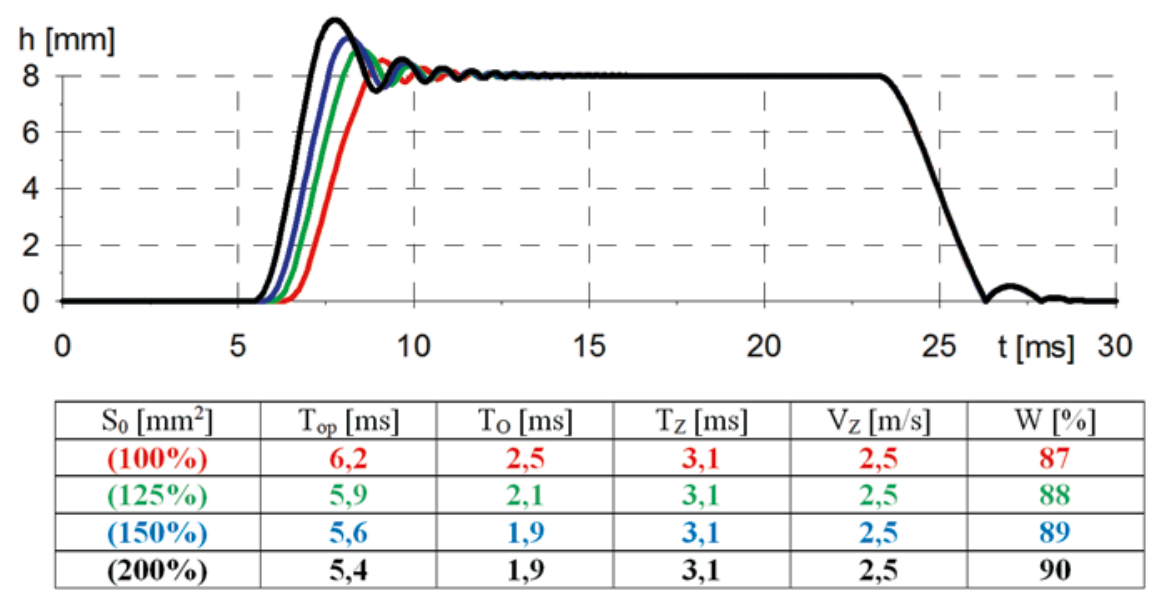

Rys. 7. Wpływ szczeliny zasilającej rozdzielacza na przebieg wzniosu zaworu

\section{Wpływ szczeliny przelewowej rozdzielacza $S_{z}$}

Wpływ wielkości szczeliny przelewowej na przebieg wzniosu zaworu przedstawiono na rysunku 8. Zmniejszenie szczeliny przelewowej rozdzielacza powoduje wydłużenie czasu zamykania zaworu, zmniejszenie prędkości osiadania zaworu w gnieździe oraz zmniejszenie wypełnienia pola pod wzniosem zaworu. Zmniejszenie prędkości osiadania zaworu jest oczywiście korzystnym skutkiem ewentualnej modyfikacji zaworu, wydłuża ono jednak czas zamykania zaworu, czym powoduje zmniejszenie wskaźnika wypełnienia pola pod krzywą wzniosu.

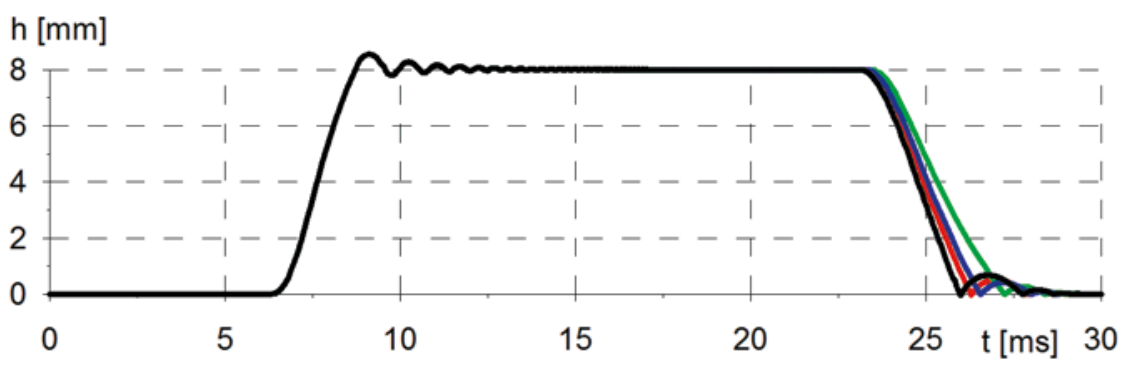

\begin{tabular}{|c|c|c|c|c|c|}
\hline $\mathrm{S}_{\mathrm{Z}}\left[\mathrm{mm}^{2}\right]$ & $\mathrm{T}_{\text {op }}[\mathrm{ms}]$ & $\mathrm{T}_{\mathrm{O}}[\mathrm{ms}]$ & $\mathrm{T}_{\mathrm{Z}}[\mathrm{ms}]$ & $\mathrm{V}_{\mathrm{Z}}[\mathrm{m} / \mathrm{s}]$ & $\mathrm{W}[\%]$ \\
\hline$(\mathbf{1 0 0} \%)$ & $\mathbf{6 , 2}$ & 2,5 & 3,1 & 2,5 & 87 \\
\hline$(\mathbf{5 0} \%)$ & 6,2 & 2,5 & 3,9 & 1,6 & 86 \\
\hline$(\mathbf{7 5} \%)$ & $\mathbf{6 , 2}$ & $\mathbf{2 , 5}$ & 3,3 & 2,2 & $\mathbf{8 5}$ \\
\hline $\mathbf{( 2 0 0} \%)$ & $\mathbf{6 , 2}$ & $\mathbf{2 , 5}$ & $\mathbf{2 , 9}$ & $\mathbf{2 , 9}$ & $\mathbf{8 4}$ \\
\hline
\end{tabular}

Rys. 8. Wpływ szczeliny przelewowej rozdzielacza na przebieg wzniosu zaworu 


\section{Wpływ średnicy tłoka siłownika hydraulicznego d}

Wpływ średnicy tłoka siłownika hydraulicznego na przebieg wzniosu zaworu przedstawiono na rysunku 9 i w tabeli 1.
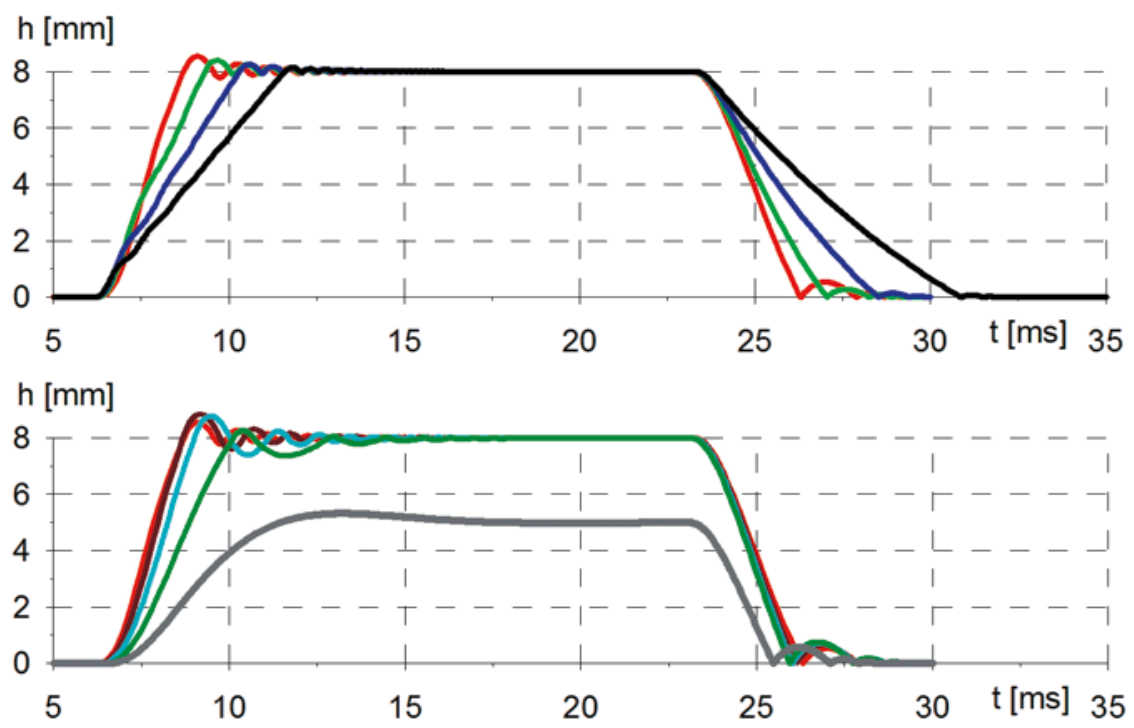

Rys. 9. Wpływ średnicy tłoka siłownika hydraulicznego na przebieg wzniosu zaworu

Tab. 1. Wpływ średnicy tłoka siłownika hydraulicznego na parametry ruchu zaworu

\begin{tabular}{|c|c|c|c|c|}
\hline $\mathrm{d}[\mathrm{mm}]$ & $\mathrm{T}_{\text {op }}[\mathrm{ms}]$ & $\mathrm{T}_{\mathrm{O}}[\mathrm{ms}]$ & $\mathrm{T}_{\mathrm{Z}}[\mathrm{ms}]$ & $\mathrm{V}_{\mathrm{Z}}[\mathrm{m} / \mathrm{s}]$ \\
\hline $4, \mathbf{0}$ & & & & \\
\hline $\mathbf{5 , 0}$ & $\mathbf{6 , 3}$ & 3,8 & $\mathbf{2 , 9}$ & 3,1 \\
\hline 6,0 & 6,3 & 2,7 & 2,9 & 3,0 \\
\hline $\mathbf{7 , 0}$ & $\mathbf{6 , 2}$ & $\mathbf{2 , 4}$ & $3, \mathbf{0}$ & $\mathbf{2 , 8}$ \\
\hline $\mathbf{8 , \boldsymbol { 0 }}$ & $\mathbf{6 , 2}$ & $\mathbf{2 , 5}$ & 3,1 & $\mathbf{2 , 5}$ \\
\hline $\mathbf{1 0 , 0}$ & $\mathbf{6 , 2}$ & 3,1 & 3,8 & 1,7 \\
\hline $\mathbf{1 2 , 0}$ & $\mathbf{6 , 2}$ & $\mathbf{4 , 1}$ & $\mathbf{5 , 3}$ & $\mathbf{1 , 1}$ \\
\hline $\mathbf{1 4 , 0}$ & $\mathbf{6 , 2}$ & $\mathbf{5 , 4}$ & $\mathbf{7 , 6}$ & $\mathbf{0 , 9}$ \\
\hline
\end{tabular}

Zwiększanie średnicy tłoka siłownika hydraulicznego powoduje znaczne zwiększanie chłonności komory siłownika. Skutkuje to wydłużeniem czasów otwierania i zamykania zaworu oraz zmniejszeniem wypełnienia pola pod krzywą wzniosu zaworu. Wpływ ten jest szczególnie widoczny dla średnic siłowników większych od $10 \mathrm{~mm}$. Jedynym pozytywnym skutkiem takiej modyfikacji jest znaczne zmniejszenie prędkości osiadania zaworu w gnieździe. 
Analizując uzyskane wyniki można stwierdzić, że zarówno zwiększanie jak i zmniejszanie średnicy siłownika nie powoduje poprawy parametrów napędu. Ze względu na niewielki wydatek czynnika roboczego nawet dla dużych ciśnień zasilania rozdzielacz Caterpillar nie nadaje się dla większych siłowników hydraulicznych. Mniejsze średnice tłoka siłownika nie zapewniają natomiast odpowiednio dużej siły.

\section{Wpływ napięcia wstępnego sprężyny zaworowej $y_{0}$}

Wpływ napięcia wstępnego sprężyny zaworowej na przebieg wzniosu zaworu przedstawiono w na rysunku 10. Zwiększanie napięcia wstępnego sprężyny zaworowej z jednej strony zwiększa zwłokę zadziałania napędu oraz czas otwierania zaworu, a z drugiej zmniejsza czas zamykania zaworu zwiększając prędkość osiadania zaworu w gnieździe. Jednocześnie, dzięki odwrotnemu oddziaływaniu na fazę otwierania oraz zamykania zaworu wypełnienie pola pod wzniosem zaworu nie zmienia się. Zmiana tego parametru, ze względu na parametry wytrzymałościowe sprężyn oraz ich częstotliwości drgań własnych, może odbywać się tylko w niewielkim zakresie.

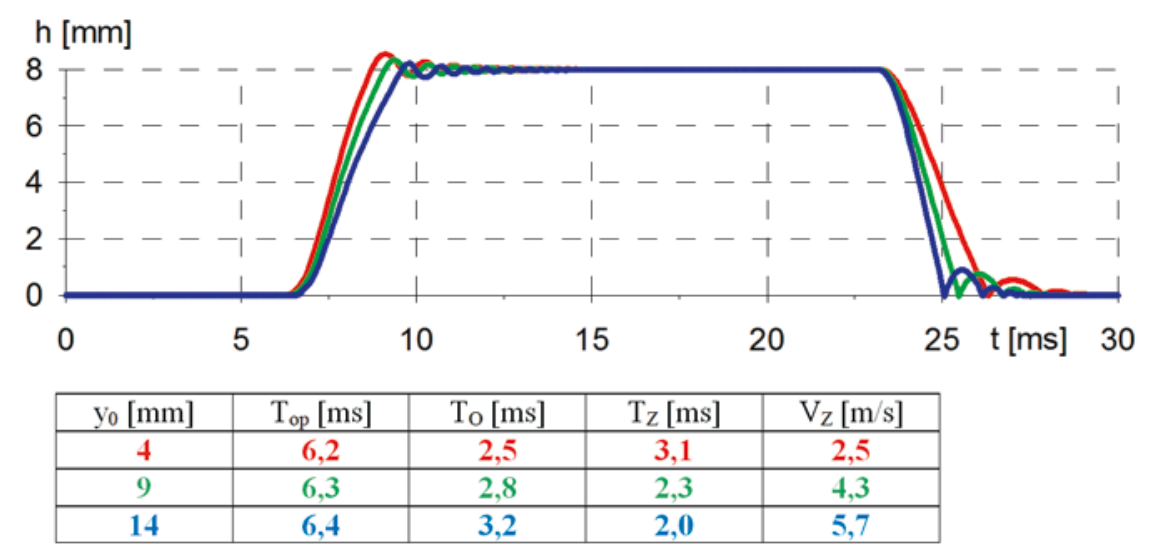

Rys. 10. Wpływ napięcia wstępnego sprężyny zaworowej na przebieg wzniosu zaworu

\section{Wpływ stałej sprężyny zaworowej k}

Wpływ wartości stałej sprężyny zaworowej na przebieg wzniosu zaworu przedstawiono na rysunku 11. Zwiększanie stałej sprężyny zaworowej z jednej strony zwiększa zwłokę zadziałania napędu oraz czas otwierania zaworu, a z drugiej zmniejsza czas zamykania zaworu, zwiększając znacznie prędkość osiadania zaworu w gnieździe. Jednocześnie, dzięki odwrotnemu oddziaływaniu na fazę otwierania oraz zamykania zaworu wypełnienie pola pod wzniosem zaworu zwiększa się w niewielkim stopniu. Wydaje się, że korzystniejsze dla napędu byłyby możliwie duże stałe sprężyny zaworowej, co dodatkowo będzie powodowało zwiększenie wartości częstotliwości rezonansowej sprężyny. 


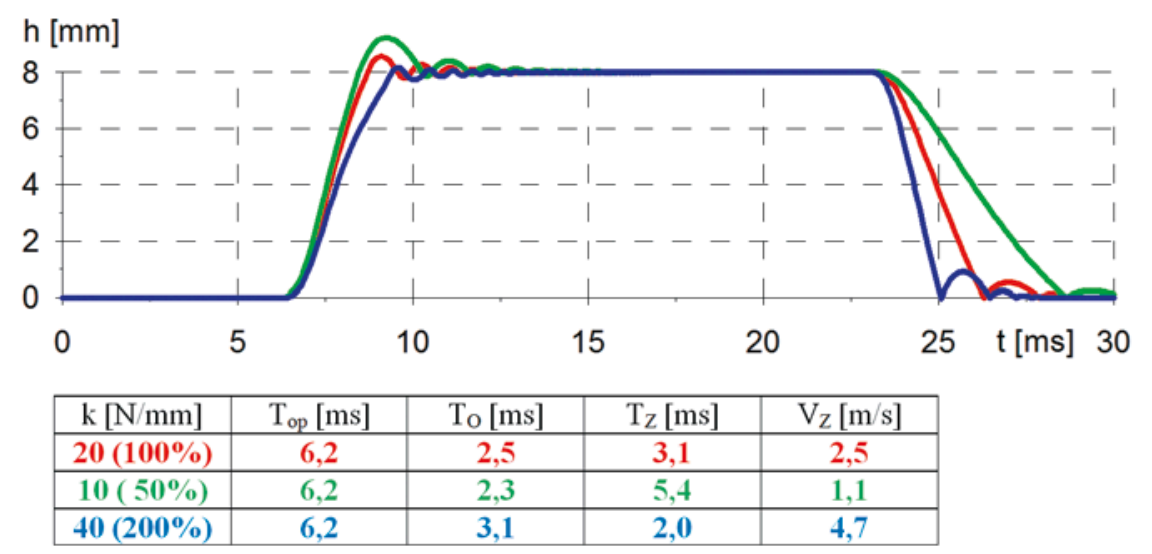

Rys. 11. Wpływ stałej sprężyny zaworowej na przebieg wzniosu zaworu

\section{Wpływ charakterystyki sprężyny zaworowej}

Wpływ charakterystyki sprężyny zaworowej na przebieg wzniosu zaworu przedstawiono na rysunku 12. W ramach badań symulacyjnych wykonano próby dla napędu ze skokowo zmienną charakterystyką elementu sprężystego zaworu. Powyżej 75\% wzniosu zaworu zwiększono skokowo stałą sprężyny. Zmienna charakterystyka sprężyny nie wydłużała w istotny sposób czasu otwarcia zaworu, a pozwalała ograniczenie niekorzystnego zjawiska odrywania się trzonka zaworu od tłoczyska siłownika. Ponadto wraz ze wzrostem dodatkowej sztywności w końcowej fazie skoku zaworu skracał się czas jego zamykania zaworu , co korzystnie wpływało na wskaźnik wypełnienia pola pod krzywą wzniosu zaworu.

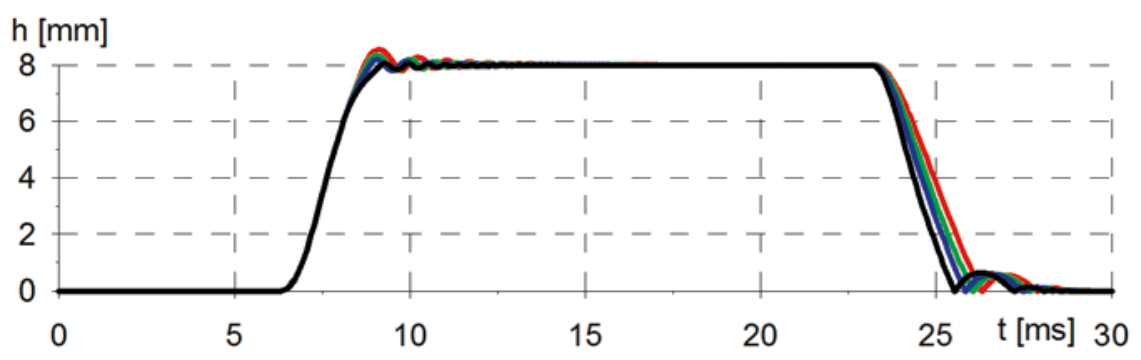

\begin{tabular}{|c|c|c|c|c|}
\hline $\mathrm{dk}[\mathrm{N} / \mathrm{mm}]$ & $\mathrm{T}_{\text {op }}[\mathrm{ms}]$ & $\mathrm{T}_{\mathrm{O}}[\mathrm{ms}]$ & $\mathrm{T}_{\mathrm{Z}}[\mathrm{ms}]$ & $\mathrm{V}_{\mathrm{Z}}[\mathrm{m} / \mathrm{s}]$ \\
\hline$+(\mathbf{0} \%)$ & 6,2 & 2,5 & 3,1 & 2,5 \\
\hline$+(25 \%)$ & 6,2 & 2,6 & 2,9 & 2,5 \\
\hline$+(\mathbf{5 0} \%)$ & $\mathbf{6 , 2}$ & 2,6 & 2,7 & 2,6 \\
\hline
\end{tabular}

Rys. 12. Wpływ charakterystyki sprężyny zaworowej na przebieg wzniosu zaworu 


\section{Podsumowanie}

Artykuł prezentuje wyniki symulacyjnych badań właściwości elektrohydraulicznego napędu jednostronnego działania dla zaworu silnika. Informacje zdobyte podczas tych badań pozwoliły na określenie podstawowych właściwości badanego napędu tego typu oraz wytycznych i zaleceń konstrukcyjnych, co jest istotne z punktu widzenia dalszych prac mających prowadzić do opracowania prototypu elektrohydraulicznego napędu zaworu silnika.

Zawarty w przedstawionej pracy materiał daje podstawy do określenia wpływu wybranych parametrów elektrohydraulicznego napędu zaworu rozrządu silnika spalinowego na jego właściwości. Dzięki przeprowadzonym badaniom można wskazać następujące najważniejsze wnioski:

- ze względu na niewielki wydatek rozdzielacza Caterpillar nie nadaje się on do zastosowania w napędzie większych zaworów - możliwe jest wykorzystanie go tylko do napędu małych zaworów szybkoobrotowych silników samochodowych;

- ze względu na zwłokę zadziałania oraz szybkość otwierania zaworu konieczne jest zastosowanie układów sprężenia zwrotnego dla wypracowania wyprzedzenia sygnału sterującego w stosunku do żądanej chwili otwarcia zaworu;

- dla możliwości zastosowania takiego napędu w silnikach szybkoobrotowych konieczne są stosunkowo duże ciśnienia zasilania - nawet około $20 \mathrm{MPa}$ oraz jak największe napięcia zasilania (z układem forsowania prądem otwarcia rozdzielacza);

- dla zastosowania w silnikach szybkoobrotowych konieczna jest specjalna zabudowa takiego rozdzielacza minimalizująca objętość komory roboczej oraz przewodów łączących rozdzielacz z siłownikiem - koniecznym wydaje się zabudowa rozdzielacza bezpośrednio na siłowniku hydraulicznym;

- dla szerszego zastosowania takiego napędu rozrządu konieczne byłyby następujące modyfikacje rozdzielacza: zwiększenie sprawności elektromagnesu zwiększające jego siłę elektromagnetyczną oraz zwiększenie przekroju szczeliny zasilającej.

Szczegółowe analizy zawarte w pracy mogą być podstawą do dalszych badań nad hydraulicznym napędem zaworu rozrządu. 


\section{Literatura}

[1] BARROS da CUNHA S., HEDRICK K., PISANO A.: Variable Valve Timing By Means of a Hydraulic Actuation. Society of Automotive Engineers 2000, SP-1523.

[2] SMOCZYŃSKI, M., SZYDŁOWSKI, T.: Model of Hydraulic Single-acting Drive for Valves of Internal Combustion Engines. Journal of KONES: Powertrain and Transport, Vol. 16, No. 1, pp. 465 472, 2009.

[3] ZBIERSKI, K., SMOCZYŃSKI, M.: Motion Properties of Hydraulically Actuated Valve Train. Journal of KONES:

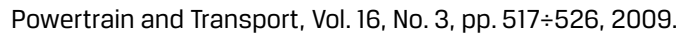

[4] ZBIERSKI, K.: Koncepcja i bezsilnikowe badania bezkrzywkowego elektrohydraulicznego rozrządu tłokowego silnika spalinowego. Journal of Internal Combustion Engines, Kones 2006, Nałęczów 2006. 